\title{
原著
}

実験的除神経・廃用筋の収縮弛緩にかんする研究

ジストロフィー筋との対比検討を中心として

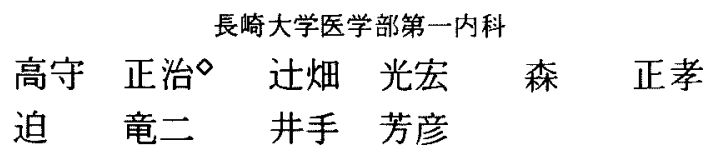

\section{CONTRACTION-RELAXATION PROPERTIES OF EXPERIMENTAL DENERVATED AND IMMOBILIZED MUSCLE : COMPARISON WITH DYSTROPHIC MUSCLE}

Masaharu TAKAmori, MD, Mitsuhiro Tsujihata, MD, Masataka Mori, MD, Ryuji HazAma, MD and Yoshihiko IDE, MD

The First Department of Internal Medicine, Nagasaki University School of Medicine, Nagasaki

\begin{abstract}
摡要 筋細胞の諸性質が神経制御下にあることは周知のことであるが，一方筋自体にその制御機構が あることも事実である．本研究はactive stateの概念のもとに，家兔の実駼的除神経，廃用筋の収縮 弛楥機構を調べ，その結果とヒト・ジストロフィー筋とを対比検討し，本病の成因，病態にかかわる neurotrophic factorの役割々限界，打よび笳自体のactivityの演ずる役割を調べた．(1) 筋小胞体 $\mathrm{Ca}^{++}$ 動態を反映する単収縮張力発生加速度低下や， $\beta$ 受容体を介する対ェピネフリン異常反応は，除神経 筋のみに認めた。 (2) 筋小胞体 $\mathrm{Ca}^{++}$動熊のみでなく，トロポニンによるCa ${ }^{++}$-binding以後のプロセス や，収縮蛋白を表現する単収縮張力弛緩時間，階段現象，強縮負荷後誘発単収縮張力の弛緩時間延長 現象, 強縮張力とその発生速度など諸指標の異常は, 除神経, 廃用両筋群に認めるが, 後者で著明て あつた. (3) 筋小胞体 $\mathrm{Ca}^{++}$遊離・結合過程に作用するカフェインに対し，ヒト・ジストロフィー筋同 様正常以下の反応を示すのは廃用筋であつた。 (4) カフェインとは一部異るステップを介し興奮収縮 連関に作用するダントロレンには，ジストロフィー，除神経，廃用三筇群とも正常反応を示した．以 上の諸結果から，本病の病態をもたらす機序には，神経，筋両因子異常の重合が多く，単一でない複 雑さが示唆された。
\end{abstract}

\section{緒言}

神経性栄養因子neurotrophic factorが筋の電気 的, 化学的, 機械的諸性質をコントロールする役 割については，神経交叉支配実験をはじめとして， 神経筋接合, 軸索流, 筋活性などを色々变えるこ

〔昭和52年 8 月 18 日受稿〕

本論文の要旨の一部は, Fifth International Conference of the Muscular Dystrophy Association (Durango, Colorado, USA, June, 1976) 招待檴演，找上 び第18回日本神経学会総会(名古屋市，1977年 5 月) 一般講演において発表した。
とによる影響を観察することによつて研究が行な われて来た。このneurotrophic factorの概念は, 進行性筋ジストロフィー症の神経原説に一つの支 持を与えて来たものの，決定的な結論を下すには 至つていない，すなわら，神経一筋の関係は正常 に維持したまま， disuse，overuseの諸処置を施す ことによつて，筋収縮性を変化調節出来ることか ら，少なくとも一部筋自体の活性が担ら役割も論 じられてる. tenotomized, denervated musclesに 異なる頻度の電気刺激を人工的に与えることによ 
り，それぞれの頻度に応じてその筋の収縮性を調 節出来るといら実験もあり，神経交叉支配実験の 結果は, 運動ニューロンに特異的なchemotrophic factorが存在するためではなく, nerve impulseの パターン (phasic, tonic) の変化によると解釈する 考光方もある。乙かし筋活性に関する串験でも， fast筋とslow筋を人工的に相互完全に転換出来る ものではない．われわれは，先にヒト・ジストロ フィ一の特に末梢筋で, 神経筋伝達, 筋表面膜な ど電気的指標で表現されるレベルに，生理学的手 段でみるかぎり，まだ異常が認められない，いわ ゆる病初の時期を選んで，筋張力曲線分析を中心 に検討した。 その結果, 筋細胞内機構, および, その膜受容体を介する対カテコルアミン反応性に 異常が存在することを明らかにしだ．

病的プロセスが進行し，活動電位など電気的指 標に变化をみる時期に筋張力を分析しても, 細胞 下構造の表現は，表面膜電気的变化によつて修飾 され，真の姿を観察出来ない括それがあり，また あまりに進行した時期では, 非特異的変化の占め る部分が多くなり，シストロフィ一筋に特異的に 存在するかもしれない異常を見逃すきらいがあ る. 本研究は，この点を留意した上で，時期を選 んだ家鬼実験筋の諸変化と上述ジストロフィ一筋 のそれを対比し，ジストロフィ一筋收縮弛緩の諸 異常のらち，いずれが神経因子を，いずれが筋自 体の因子を，よりつょく反映しているものかを調 へたた，神経因子の検討には，支配神経切断一定時 間後の筋を用い，筋自体の因子の検討には，関節 固定によるimmobilized筋（以下 “廃用筋” と呼 ぶ）を用いた，後者では，末梢神経および神経筋 接合の状態は正常のままであり，コリン作働性シ ナプス，括よびその他に筋に対して何らかの影響 を及ぼすと仮想される因子の可能性も含めて，正 常に維持されたをを，注湾不動の状態にある。こ の条件下で，筋肉側細胞膜，細胞内諸機能に変化 をみるとすれば，それは筋自体の活性の影響をう けたものとして評価出来よう。

方 法
Pentobarbitone sodium (20mg $/ \mathrm{kg}$ ) 麻酷下 の家 鬼（体重 $2 \sim 2.5 \mathrm{~kg}$ ）前怪骨筋を用いた， denervation実験は，10羽の家鬼について，右坐骨神経 を前怪骨筋より約 $8 \mathrm{~cm}$ proximalの部位で切断, 該部皮膚は無菌的に 槰合したのち，20〜24時間 後, 神経刺激による誘発筋活動電位振幅低下ある る筋直接刺激によるそれはまだ不変である時期 (すなわち筋表面膜レベルに先行して神経筋伝澾 レベルに異常が始まる時期）を選んで分析した. 針電極筋電図でfibrillationや刺入活動電位増大を みないことも確認した。 immobilization実験は, 10羽の家鬼につき, 右脚膝, 足関節をキルシナー 鋼線で $90^{\circ}$ に固定(無菌的)，4 週間後に行なつた。 両実験の各家鬼で，左前怪骨筋はコントロールK 供した. 生理学的実験のあとは, 当該筋は対側の コントロール筋とともに, 重量測定と病理組織学 的検查 (hematoxylin-eosin扰よびmasson-trichrome 染色とmyofibrillar ATPase活性) 飞供した。

電気生理学的実験は, 各家鬼を膝, 足関節部固 定台の上に仰卧位とし， pentobarbitone麻酔下 (20

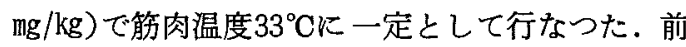
怪骨筋活動電位は，間接刺激の場合は淢窩部で露 出した腓骨神経に白金線電極を掛け，直接刺激の 場合は筋に直接刺入した双極針電極を介して, 矩 形波電気刺激し誘発した。記録にはmid-belly括よ びtendonに 接着した 銀盤表面電極（直経 $1.5 \mathrm{~mm}$ ) を用いた。直接刺激では, 筋肉内神経の刺激を避 けるため，0.03\%d-tubocurarine chlorideを耳介 静脈を介して, 電動式微量注入器を用い注入下に 行なつた。前怪骨筋張力は, 同筋および腱の一端 を周囲から切り離して水平方向にステンレス鋼線 を掛け, isometric strain gauge myographに連結 し, 上述直接刺激法で誘発, 記録した。静止時張 力は, 最大単収樎力が得られる張力をひつて固定 した，単一刺激で誘発する単収縮張力曲線から は, 最大単収縮力 $(\mathbf{P t})$, 張力発生からPtを経て その $1 / 2$ の張力すて弛緩する時間 $\mathrm{T}^{1} / 2 \mathrm{R}$, 活動電位 発生時から張力の一次微分ピーク值 (張力発生最 大速度） での時間 $\mathrm{TdP} t / d t$, 張力の二次微分ピー 


\begin{tabular}{|c|c|c|}
\hline Abbreviations & Measurements & Active state properties \\
\hline $\mathrm{Pt}$ & 最大単収䊒张力 & $\begin{array}{l}\text { Force generated by contractile component } \\
\text { plus series elastic component. }\end{array}$ \\
\hline $\mathrm{T}_{\mathbf{1} / \mathbf{2 R}}$ & 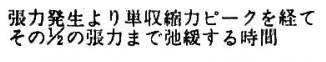 & Decay of active state. \\
\hline $\mathrm{TdPt} / \mathrm{dt}$ & 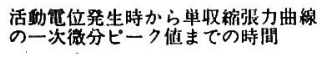 & Duration of active state. \\
\hline$d^{2} \mathrm{Pt} / \mathrm{dt}^{2}$ & 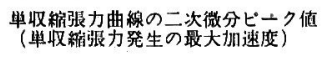 & Active state intensity of shortening. \\
\hline Po & 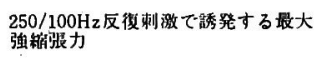 & Active state intensity of load-bearing. \\
\hline $\mathrm{dPo} / \mathrm{dt}$ & 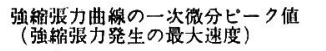 & $\begin{array}{l}\text { Force-velocity relation; Rate of fomation } \\
\text { of cross-bridges; Series-elastic component, }\end{array}$ \\
\hline
\end{tabular}

ク值 (張力発生最大加速度) $\mathrm{d}^{2} \mathbf{P t} / \mathrm{dt}^{2}$ を測定した。 また $100 \mathrm{~Hz}$ 反復刺激で強縮張力曲線を描き，その 最大值Poと, 一次微分 ピーク值 $\mathrm{dPo} / \mathrm{dt}$ 記録し た。これら筋収縮弛緩の生理学的諸指標の 意義 付けは， active stateの概念にもとづき表 1 亿示 才(1) -3).

単収縮張力の階段現象 (staircase phenomenon) は $1 \mathrm{~Hz}$ 反復刺激を 2 分間与兄, 第 120 発目の単収 縮を第 1 発目のそれと比較計算して算出した. 強 縮負荷後誘発の単収縮張力增大現象 (posttetanic potentiation)は， $50 \mathrm{~Hz}$ 反復刺激 10 秒間の強縮負荷 後 1 分目に誘発した単収縮を, 負荷前誘発の単収 縮と比較算出した。いずれの場合も，同時記録の 筋活動電位は，刺激負荷前後で変化しないこと， 誘発単収縮張力は, 前者で負荷終了後10分目まで, 後者で負荷終了後15分目までに，それぞれ負荷前 の状態にもどることを条件とした．

薬理学的検査では, 耳介静脈を介して, isoproterenol $(5 \mu \mathrm{g} / \mathrm{kg})$, caffeine $(50 \mathrm{mg} / \mathrm{kg})$, dantrolene ( $4 \mathrm{mg} / \mathrm{kg})$ を注入し, 筋張力曲線諸指標を, 薬剤 投与前後で比較測定した。なお，ヒト・ジストロ フィー筋張力の対エピネフリン反応測定について は別報に述べだ。本報で詳述する対ダントロレ ン反応の対象には，末梢筋に電気的指標異常の来 ていない肢帯型筋ジストロフィー症 5 例, 正常コ ントロール (age-matched) 5 例をえらんだ。本 剂100mg内服 3 時間後, 尺骨神経刺激で誘発する 母指内転筋の等尺性単収縮力 $\mathrm{Hz}$ 反復刺激）を測定，微分分析し，同時誘発の
筋活動電位とともに，投与前のそれと比較した。

$$
\text { 結。果 }
$$

\section{I. 单収縮, 強縮張力}

正常神経支配の家鬼前怪骨筋（20例）から得ら れた測定値は, 最大単収縮力 (Pt) $104 \sim 144 \mathrm{~g}$, $1 / 2$ 弛緩時間 $\left(\mathrm{T}^{1} / 2 \mathrm{R}\right) 37 \sim 48 \mathrm{msec}$, 最大強縮力 $(\mathrm{Po})$ 690〜1000 gで，それぞれの微分分析の結果を含 めFig 1 (shadow) に示している. 坐骨神経切断 による除神経筋 (10例, Fig 1 ・印) の筋張力分 析値は，筋直接刺激に上る誘発筋活動電位振幅は 正常範囲内 $(22 \sim 26 \mathrm{mV})$ にあるが, 神経刺激に上 るそれには低下 $(8.8 \sim 19 \mathrm{mV})$ がみられる時期を えらんで得たものである４ 4 週間immobilization による廃用筋（10例，Fig $1 \times$ 印）では，神経 刺激・筋直接刺激とも誘発筋活動電位振幅は等し く,かつ正常範囲内にあつた．除神経筋で特に異 常な指標は, 張力発生加速度 $\left(\mathrm{d}^{2} \mathbf{P} \mathrm{t} / \mathrm{dt}^{2}\right)$ の低下に 伴う単収縮力 $(\mathrm{Pt})$ の低下であり, 廃用筋で目立 つのは, 単収縮張力曲線の弛緩時間 $\left(T^{1} / 2 R\right)$ 延長 と, 強縮力 $(\mathrm{Po})$ およびその発生速度 $(\mathrm{dPo} / \mathrm{dt})$

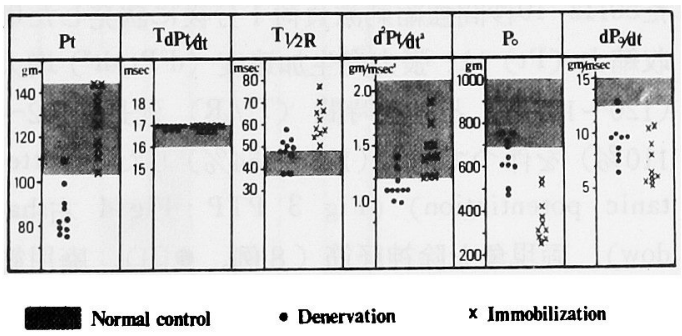

Fig 1. Effects of denervation and immobilization on contractile properties 


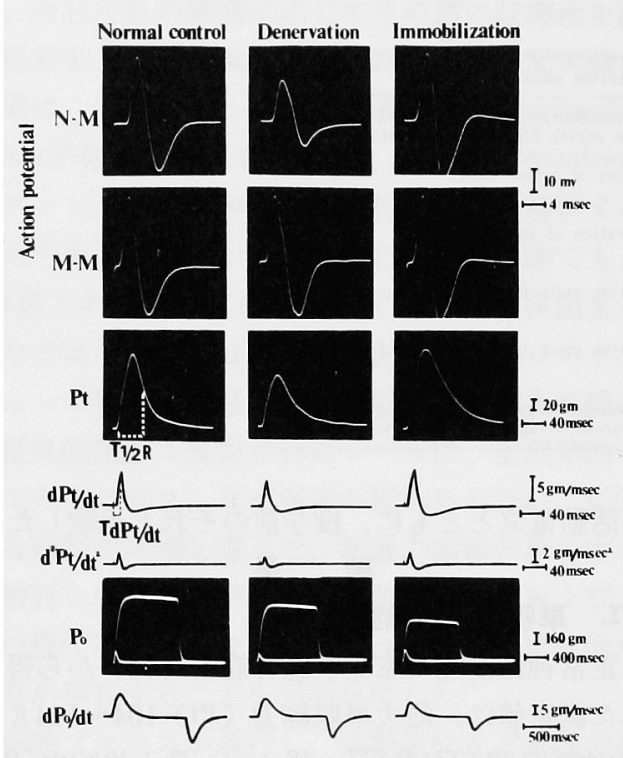

Fig 2

の低下であつた。正常, 除神経, 廃用諸筋張力曲 線とその分析の実例をFig 2 亿示している. 組織 化学検查では正常筋type II fiber dominant, 廃用 筋にfiber type atrophy, 結合織増加なく重量低下 はー11〜ー22\%であつた。

\section{Staircase phenomenon ¿ posttetanic p- otetiation}

正常神経支配の家鬼前怪骨筋（16例）を， $1 \mathrm{~Hz}$ 2 分間, 直接反復刺激した結果, 単収縮張力発生 加速度 $\left(\mathrm{d}^{2} \mathrm{Pt} / \mathrm{dt}^{2}\right)$ の増大 (125 160\%) と弛緩 時間 $\left(\mathrm{T}^{1} /{ }_{2} \mathrm{R}\right)$ の短縮 (87 94\%) を伴う単収縮力 （Pt）増大（115～139\%）がみられた（staircase phenomenon) (Fig $3 \mathrm{SC}$; Fig 4 左shadow). ま た $50 \mathrm{~Hz} 10$ 秒間強縮刺激負荷 1 分後に誘発した単 収縮力 $(\mathrm{Pt})$ は, 張力発生加速度 $\left(\mathrm{d}^{2} \mathrm{Pt} / \mathrm{dt}^{2}\right)$ 増大 $(120 \sim 157 \%)$ と弛緩時間 $\left(\mathrm{T}^{1} /{ }_{2} \mathrm{R}\right)$ 延長 (102 $110 \%)$ を伴つて増大 (128～154\%) した（posttetanic potentiation) (Fig 3 PTP; Fig 4 右shadow). 両現象を除神経筋 (8 例, 一印), 廃用筋 （8例， ×印）について調べ，上述正常コントロ 一ル (shadow) と対比し，まとめてFig 4 に示し ている. staircase phenomenonは, 両筋群で正常
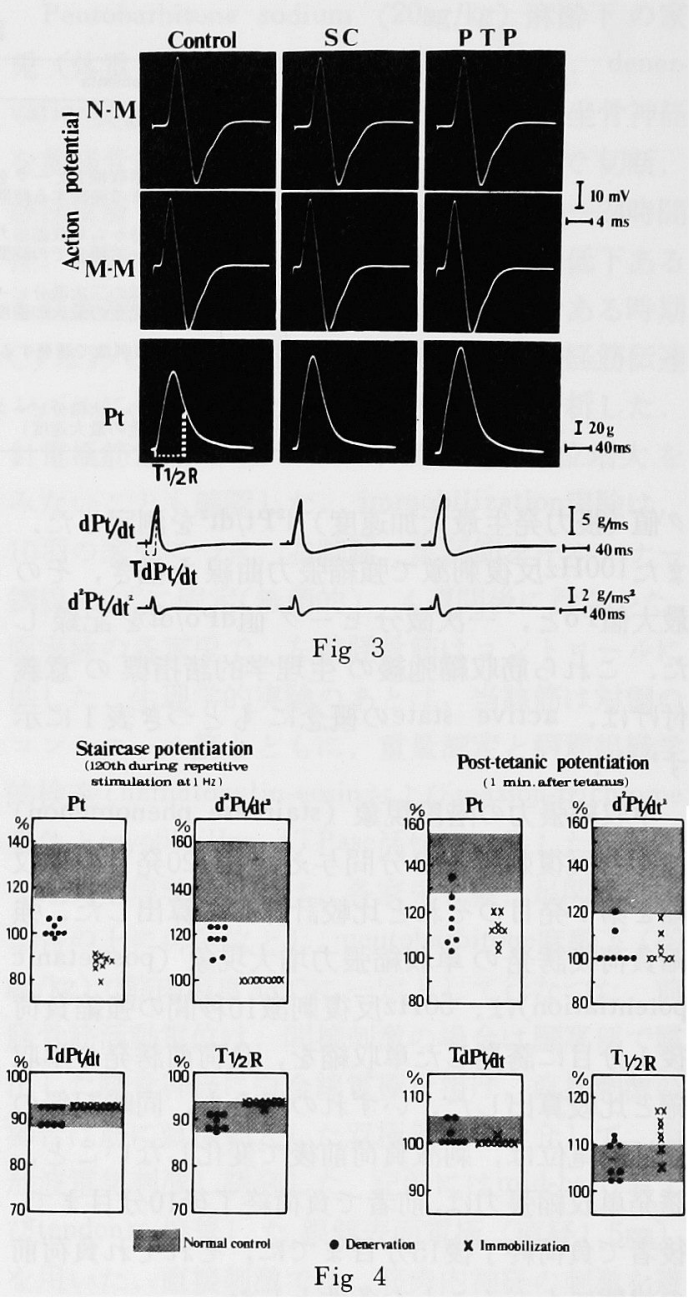

以下の増大にとどまるか，または反復刺激負荷前 レベル以下に低下 (negative staircase) するが， 定量的にみて, 特に廃用筋群に異常は著明であつ た. posttetanic potentiation 両筋群 で正常範囲 以下にとどまるが，単収縮弛緩時間 $\left(\mathrm{T}^{1} /{ }_{2} \mathrm{R}\right)$ の 異常延長は廃用筋群に著明であつた。

III. Isoproterenol, caffeine, dantroleneに 対する筋張力曲線の反応

1）対isoproterenol 反応：正常神経支配 の 家鬼前怪骨筋 (10例) の 単収縮力 $(\mathrm{Pt})$ は, isoproterenol $(5 \mu \mathrm{g} / \mathrm{kg})$ 静注 (耳介静脈) によつて, その弛緩時間 $\left(\mathrm{T}^{1} /{ }_{2} \mathrm{R}\right)$ 延長 $(+10 \sim+27 \%)$ を 


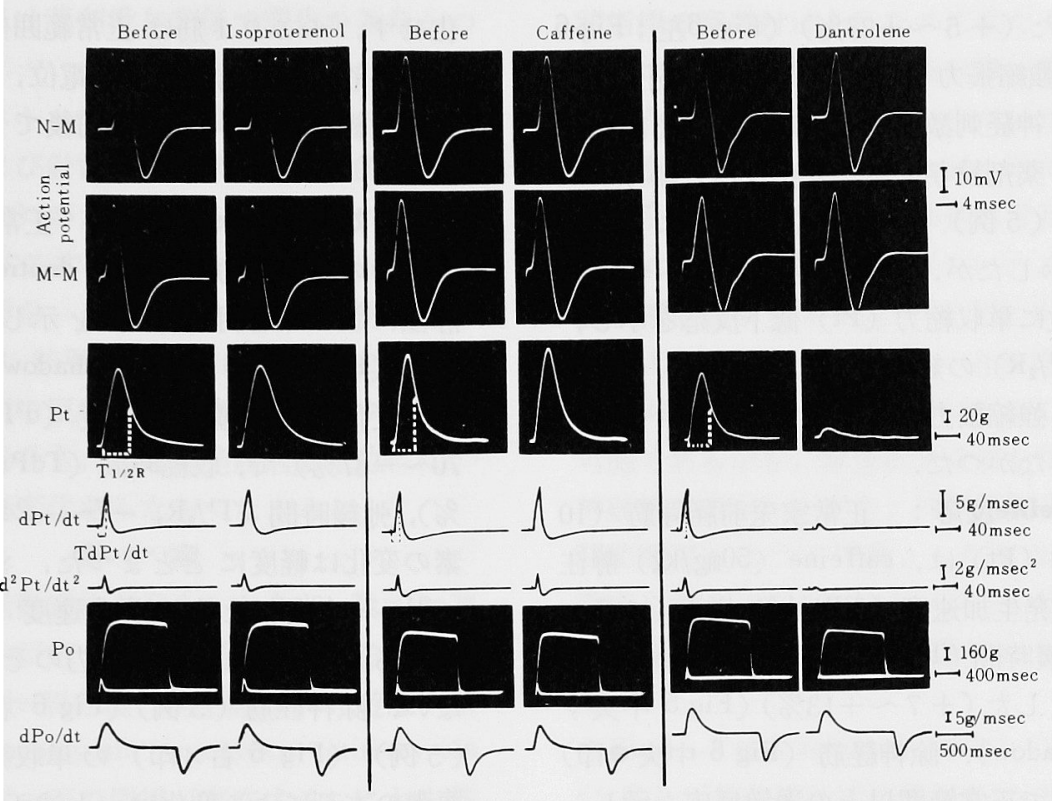

Fig 5

Effects of drugs on controactile properties
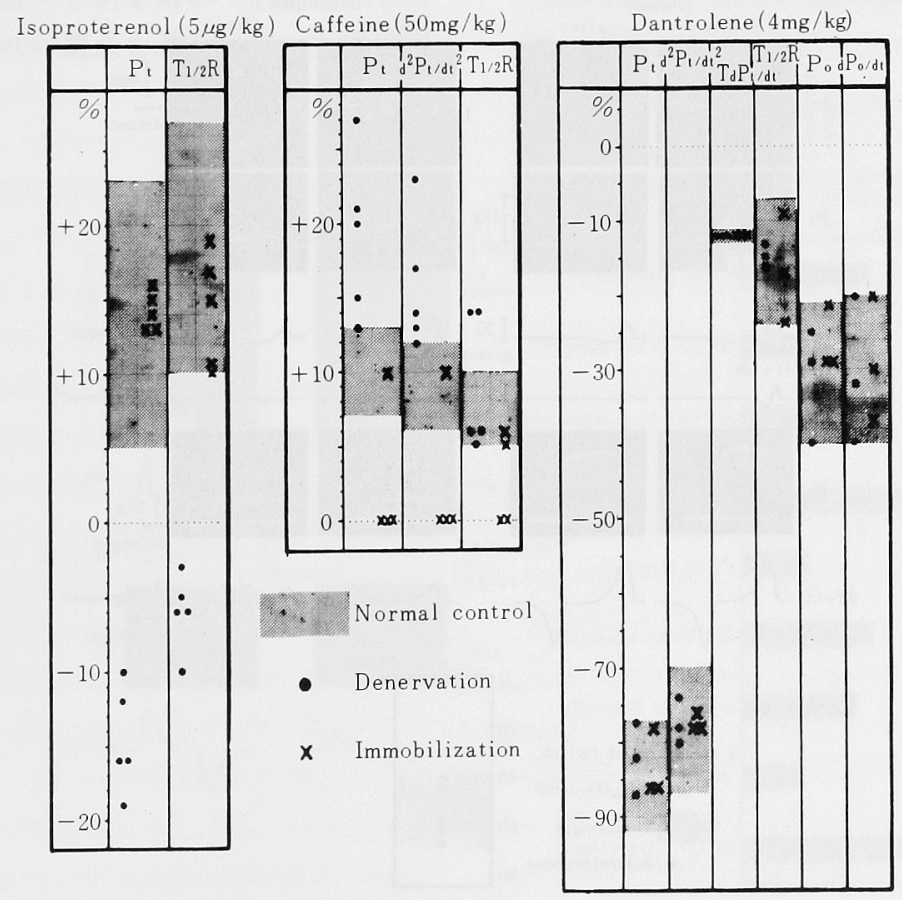

Fig 6 
伴い増大した $(+5 〜+23 \%$ ) (Fig 5左 ; Fig 6 左shadow). 強縮張力 (Po) 扰よびその発生速度 $(\mathrm{dPo} / \mathrm{dt})$ や，神経刺激・筋直接刺激による誘発活 動電位には, 薬剤投与前後で変化はみ之めなかつ た。廃用筋（ 5 例）(Fig 6 左 $\times$ 印) は正常同 椂の反応を示したが，除神経筋 (5 例) (Fig 6 左・印) は逆に単収縮力 $(\mathrm{Pt})$ 低下反応を示し, 弛緩時間 $\left(T^{1} / 2 R\right)$ の短縮を伴つていた. 各筋群 で活動電位, 強縮張力などは正常コントロール同 様変化を示さなかつた。

2) 対caffeine反応：正常家鬼前怪骨筋（10 例) 単収縮力 $(\mathrm{Pt})$ は, caffeine $(50 \mathrm{mg} / \mathrm{kg})$ 静注 により, 張力発生加速度 $\left(\mathrm{d}^{2} \mathrm{Pt} / \mathrm{dt}^{2}\right)$ 増大 $(+6 \sim$ $+12 \%)$, 弛緩時間 $\left(\mathrm{T}^{1} / 2 \mathrm{R}\right)$ 延長 $(+5 \sim+10 \%)$ を伴つて增大した $(+7 \sim+13 \%$ ) (Fig 5 中央;

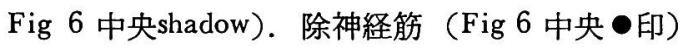
は 5 筋中 4 筋で正常範囲以上の過敏反応を示し, 一方廃用筋 (Fig 6 中央 $\times$ 印) は 4 筋中 3 筋が変
化せず，のこり1筋は 正常範囲内の 反応を示し た：各筋群で, 誘発筋活動電位, 強縮張力とその 速度曲線にはcaffeine投与前後で変化をみなかつ た。

3）対dantrolene反応：正常家鬼前怪骨筋 (7 例)の単収縮力 (Pt) は, dantrolene ( $4 \mathrm{mg} / \mathrm{kg}$ ) 静注によつて著明な低下を示した（ー77〜 -92 \%) (Fig 5 右; Fig 6 右shadow). これに伴 5 主な変化は張力発生加速度 $\left(\mathrm{d}^{2} \mathrm{Pt} / \mathrm{dt}^{2}\right)$ 低下 ( $70 \sim-87 \%$ ) で，収縮時間 ( $\mathrm{TdPt} / \mathrm{dt},-11 \sim-13$ $\%)$, 弛緩時間 $\left(\mathrm{T}^{1} /{ }_{2} \mathrm{R},-7 \sim-24 \%\right)$ など時間要 素の変化は軽度にとどまつた。 また強縮力 ( $\mathrm{Po}$, $-21 \sim-40 \%)$ とその発生速度 ( $\mathrm{dPo} / \mathrm{dt},-20 \sim$ -40\%) の変化も, 単收縮力のそれに比べると少 ない。除神経筋 ( 3 例) (Fig 6 右・印), 廃用筋 （3 例）（Fig 6 右 $\times$ 印）の単収縮, 強縮張力諸 要素の本剤による変化は, 上述正常神経支配筋の それの範囲内にあつた。いずれの場合も, 同時誘

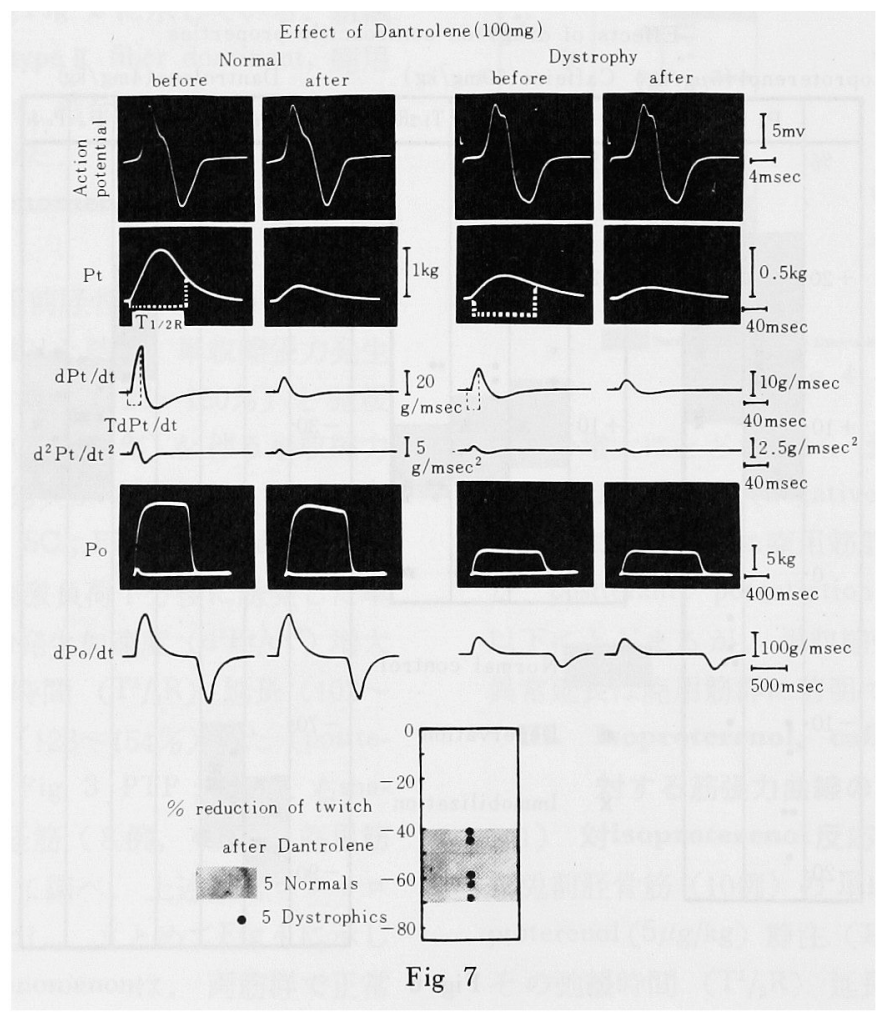


発筋活動電位には薬剂投与前後で変化をみなかつ た。

ヒト・筋ジストロフィー症肢帯型 5 例の母指内 転筋（誘発および針電極筋電図など電気的指標は 正常所見を示す）の，単収縮，強縮張力およびそ の分析值に 対する本薬剤（経口 $100 \mathrm{mg} ， 3$ 時間後 に判定）の影響を，正常コントロール5例のそれ と比較検討した結果をFig 7 に示寸。ヒト・ジ ストロフィー筋の反応は正常範囲内にあつた。 た，いずれの場合も，同時誘発筋活動電位には, 薬剤投与前後で変化をみなかつた。

\section{考案}

筋表面膜に活動電位が発生したあと，数msec遅 れて筋の機械的反応（張力）があらわれるまでの 間には, T-tubules脱分極, 筋小胞体 $\mathrm{Ca}^{++}$遊離・結 合, troponin-tropomyosin complex, actin-myosin crossbridgesなど一連の機構が存在する.これら筋 細胞内諸要素を生理学的に調べる手段として，ス トレンダージを用いて記録する等尺性単収縮, 強 縮張力曲線とその微分分析を用い（活動電位も同 時記録), active stateの概念を導入して，生理学的
諸指標の意義付けを行なつて来た（表 1$)^{1) \sim 3)}$.こ れまで, 神経筋伝達, 筋表面膜に電気生理学的指 標でみるかぎりまた異常が来ていない（膜の生化 学的变化pinternal membrane system, 筋小胞体 膜の変化についてはその存否は言及していない), 病初の時期のヒト・ジストロフィー末梢筋に， 筋収縮弛緩の 異常を証明 ${ }^{1)}$ ，Fig 8 亿その結果を 要約している。これらが，近年提唱されている neurotrophic factorの考えによつてどこまで解釈 可能であるかを，家鬼前怪骨筋を用いた実験的除 神経筋で調べた。また，神経筋接合は正常のまま 関節固定によつて不動とした廃用筋の収縮性も 測定して，ヒト・ジストロフィー筋との異同を調 ベ，筋自体因子の異常の関与についても検討し た。

Fig 1 2 はdenervation(・印), immobilization （×印）が筋収縮弛緩の諸要素に及ぼす影響を示 している. 単収縮張力発生加速度 $\left(\mathrm{d}^{2} \mathrm{Pt} / \mathrm{dt}^{2}\right)$ 低 下とともに単収縮力 $(\mathrm{Pt})$ の著明な低下を示すの は除神経筋である．廃用筋は正常範囲内であつ た。 $d^{2} \mathrm{Pt} / \mathrm{dt}^{2}$ の低下はヒト・ジストロフィ一筋の

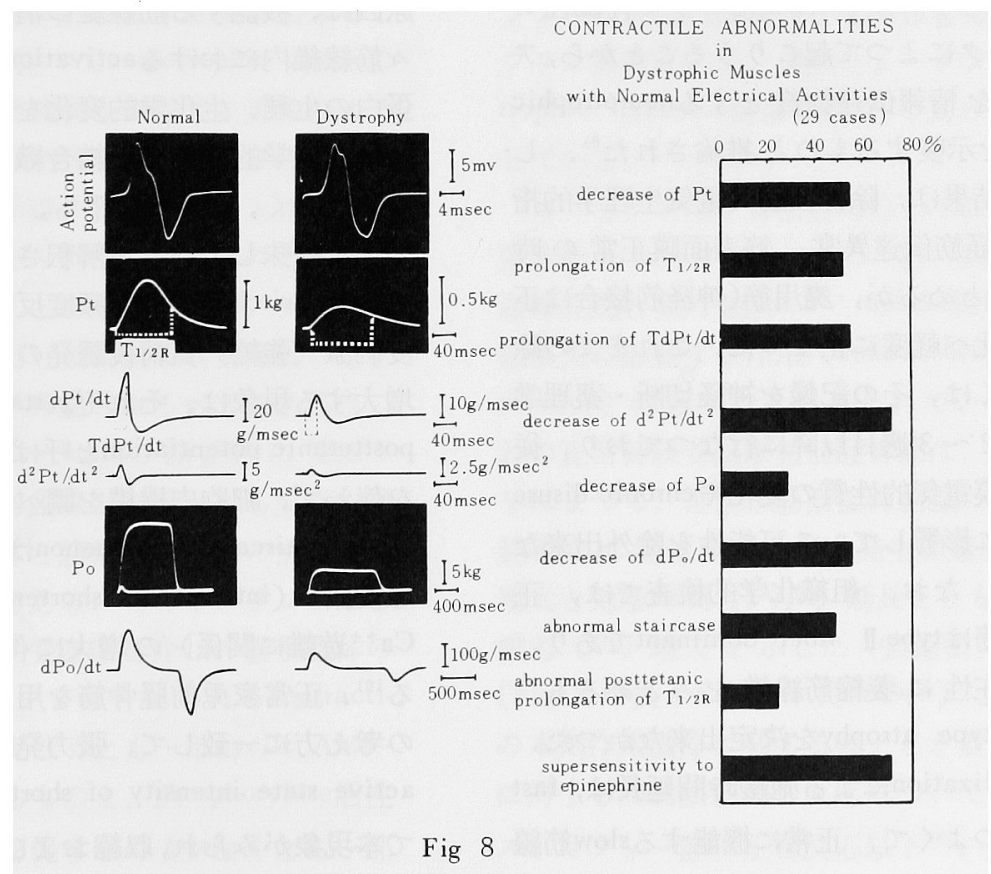


72\%にみられた異常所見でるある（Fig 8)・この 指標はactive stateの “つよさ要素” (intensity of shortening）を表現し，刺激により笳小胞体から 遊離される $\mathrm{Ca}^{++}$量を反映するとされる の除神経筋でこの指標の異常が みられたという 事実は，生化学の立場から，除神経筋の筋小胞 体 $\mathrm{Ca}^{++}$動態異常を指摘した報告 ${ }^{5)}$ も一致する。

これらの事実は，ヒト・筋ジストロフィー症で高 率に見出された本指標異常が示唆する subcellular $\mathrm{Ca}^{++}$transport systemの病的プロセスが, 神程側 (neurotrophic factor) 異常の反映であるうことを 推定せしめる.

単収縮張力弛緩時間 $\left(T^{1} / 2 R\right)$ の異常延長は，除 神経筋に比へ廃用筋に著明であつた（Fig 1，2). ヒト・ジストロフィー筋では 55\%に見出された (Fig 8). active stateの概念に基づけば，本指標 はactive state decayを表現し， troponinからの $\mathrm{Ca}^{++}$-removal と筋小胞体 $\mathrm{Ca}^{++}$再結合, およびtroponinによる $\mathrm{Ca}^{++}$-binding とmyosinkよるATP-bindingの関係を反映するものとされる ${ }^{6)}$. 単収縮張 力弛緩時間延長は，これまで除神経筋で報告さ れ7)，またotulinum toxinによるコリン作働性シ ナプス・ブロックによつて起こりらることから,ア セチルコリンを情報伀達物質とするneurotrophic influence異常を示唆するすのと推論された ${ }^{8)}$ 。し かし本研究の結果は，除神経筋（電気生理学的指 標でみて，神経筋伝達異常，筋表面膜正常の時 期)に延長はみとめるが，廃用筋(神経筇接合は正 常の状態)に比べ軽度に止まつた。これまでの除 神経実験の多くは，その記録を神経切断・薬理学 的ブロック後 $2 \sim 3$ 週目以降に行なつており, 従 つて, 筋表面膜電気的性質の変化やchronic disuse が筋張力曲線に影響している可能性を除外出来な いと思われる。な拉，組織化学的検査では，正 常家兔前怪骨筋はtype II fiber dominantであり， 廃用筋では散在性に萎縮筋線維をみとめるも， specific fiber type atrophyを決定出来なかつた。 従つてimmobilizationによる弛緩時間延長は, fast 筋線維変性がつよくて, 正常に機能するslow筋線
維の特徴が表面に出た結果であるというよりる， fiber typeに関保なく一様に起こる筋細胞内変化を 反咉したものであろう。

Active stateの“つよさ要素” (intensity of loadbearing）を表現し, actin-myosin crossbridges形成 の数と力を反映する強縮力 $(\mathrm{Po})^{6)}$ の低下は, 除 神経, 廃用両筋群でみとめるものの, 後者でより 著明であつた（Fig 1，2）。これはヒト・ジスト ロフィー筋の $28 \%$ に異常をみた指標であり（Fig 8), 本研究の結果は, これが筋自体の因子異常を よりつよく表現していることを示唆する．強縮張 力発生速度 $(\mathrm{dPo} / \mathrm{dt})$ の低下も，ヒト・ジストロ フィ一筋の55\%にみとめ (Fig 8)，これは筋収縮 要素の力一速度関係, actin-myosin crossbridges形 成率, 直列弾性要素を表現する指標とされる 本研究では，Po同様, 除神経, 廃用両筋群で本指 標の低下をみとめるが，後者で著明であり，筋自 体因子異常のよりつよい反映が示唆される。また 本実験廃用筋重量の低下は,コントロール側之比 ベた時ー11〜 -22\%で，Poの低下の著明さ（Fig 1)に平行していなかつた。従つて，Po低下の主 原因は，機能する筋線維の消失というょりも，個 々筋線維内におけるactivation processまたは収縮 蛋白の生理, 生化学的変化を示唆している。また 病理組織学的検査で, 結合織 (直列弾性要素) の 増加はなく, $\mathrm{dPo} / \mathrm{dt}$ 低下も，収縮要素そのものの 変化を意味していると解积される。

Fast twitch筋で，低頻度反復刺激中または高頻 度刺激 (強縮) 負荷後誘発の等尺性単収縮張力が 増大する現象は，それそれれstaircase phenomenon, posttetanic potentiation之呼ばれ，活動電位の変化 を伴わず，細胞内機構を調べるのに有用な現象で ある. staircase phenomenonはactive stateの"つよ さ要素” (intensity of shortening; sarcoplasmic $\mathrm{Ca}^{++}$遊離に関係) の増大に伴うものとされてい $ろ^{10)}$ ．正常家鬼前怪骨筋を用いた本研究でる，こ の考光方に一致して, 張力発生加速度 $\left(\mathrm{d}^{2} \mathrm{Pt} / \mathrm{dt}^{2}=\right.$ active state intensity of shortening)の増大に伴つ て本現象がみられ，収縮および弛緩時間 $(\mathrm{TdP} t / d t$,) 
$\left(\mathrm{T}^{1} / 2 \mathrm{R}\right.$ ) の短縮 も伴つていた (Fig 3 SC; Fig 4 左shadow). posttetanic potentiation伤篎小胞 体 $\mathrm{Ca}^{++}$遊離過程 ${ }^{11)}$ ，あるいはtroponinによる $\mathrm{Ca}^{++}$. binding以後のステッフフ ${ }^{012)}$ にその機序を求める考 え方がある．われわれの正常家鬼前怪骨筋を用い た実験でも, 強縮負荷後, 活動電位は負荷前と変 らないまま，単収縮力増大がみられた，分析する と, 張力発生加速度 $\left(\mathrm{d}^{2} \mathrm{Pt} / \mathrm{dt}^{2}=\right.$ active state intensity of shortening) の增大と, 弛緩時間 $\left(\mathrm{T}^{1} /{ }_{2} \mathrm{R}=\right.$ active state decay) 延長が伴つており, 上述の 考方方と矛盾しない結果を得た（Fig 3 PTP； Fig 4 右shadow). ヒト・ジストロフィー筋の分析 では，症例の $48 \%$ Kstaircase phenomenon異常, $24 \%$ Kosttetanic potentiationk佯万弛緩時間異 常延長をみている (Fig 8), 実験的除神経, 廃用 筋についてみると, 両筋群で両現象異常を高率に 見出すが，定量的には後者でより著明であつた (Fig 4). 本来両現象とも正常fast筋にみられるも ので，正常slow筋では条件負荷前単収縮力より低 下寸るnegative staircase phenomenon, posttetanic depressionがみられ, 特にposttetanic changesは, 神経支配交叉によつて, 増大・低下変换が出来ると する報告がある ${ }^{13)}$. 従つてneurotrophic factorの 制御下にある筋細胞内機構を表現する現象のよう に思われる.われわれの実験でる，除神経筋の示す 態度をみるとこれを示唆するものの，上述のよう に廃用筋分析の結果をみれば, 筋自体の因子の反 映るつよく受けらることが示唆される。ヒト・ジ ストロフィー筋で見出した両現象異常発現の解釈 に当つても，この点が考虑されるべきであろう．

エピネフリンがactive stateの諸要素に及洔す 作用, その結果筋張力曲線上に現われる反応を調 ベることも，膜受容体と筋細胞内機構の情報をつ かむ手段として有用である。エピネフリンのこの 面儿対する作用は， $\beta$ 受容体を介し，筋小胞体の $\mathrm{Ca}^{++}$遊離・結合でコントロールされるcontraction-relaxation cycle (少なくとも一部cyclic AMPdependent) に影響するものと, phosphorylase活性 化からglycogenolysisを促すもの（少なくとも一部 cyclic AMP-dependent) がある1).一般に，エピ ネフリン投与により，fast筋の単収縮力は，その 収縮・弛緩時間（特に後者）の延長に伴つて増大 し，slow筋は弛緩時間の短縮に伴つて低下するこ と，最大強縮力には変化をみないこと，などが知 られている ${ }^{14)}$.われわれは，ヒ卜母指内転筋につ いて調べた結果，ジストフィー症の71\%に正常 範用を越えた対エピネフリン異常低下反応をみと めた (Fig 8)1). 本研究では，これが神経因子の 反映か，筋自体の問題の反映かを明らかにする実 験を，isoproterenol ( $\beta$-stimulant)を用いて行な つた。まず正常神経支配の家鬼前怪骨筋単收縮力 ( $\mathrm{Pt}$ ） は従来の報告通り，その弛緩時間 $\left(\mathrm{T}^{1} / 2 \mathrm{R}\right)$ 延長とともに堌大し, 強縮力 (Po), 活動電位の 変化はみられなかつた(Fig 5 左； Fig 6 左 shadow). ところが除神経筋の単收縮力 $(\mathrm{Pt})$ は, isoproterenol投与により，あたかも正常神経支配 下のslow筋が示すように，弛緩時間 $\left(\mathrm{T}^{1} / 2 \mathrm{R}\right)$ の短 縮を伴つた低下反応を示した（Fig 6 左・印).一 方，廃用筋は正常同様の増大反応を示した（Fig 6 左×印).これらの事実は，上述したジストロ フィ一筋細胞内機構の $\beta$ 受容体を介した対エピネ フリン異常反応が，運動ニニーロンの筋に対する trophic influence異常の結果であろうことを示唆 している。

カフェインは，骨格筋に対しては電気的反応に 変化をもたらすことなく，筋小胞体からのCa ${ }^{++}$ 遊離促進と筋小胞体 $\mathrm{Ca}^{++}$uptake抑制とによつて 筋張力に影響する作用 (contracture, twitch potentiation) のあることが知られている れの正常神経支配家鬼前怪骨筋は，カフェイン投 与に上つて, 神経・筋直接両刺激による誘発筋活 動電位に変化なく, 張力発生加速度 $\left(\mathrm{d}^{2} \mathrm{Pt} / \mathrm{dt}^{2}\right)$ 増大と弛緩時間 $\left(\mathrm{T}^{1} /{ }_{2} \mathrm{R}\right)$ 延長とともにその単収 縮力 $(\mathrm{Pt})$ 増大を示した（強縮張力は無変化） (Fig 5 中央; Fig 6 中央shadow) ことは，上述 の本剂作用機序に関する考兄と矛盾しない，本剤 に対する病的筋張力の反応については，ヒト・ジ ストロフィー筋は正常反応以下 ${ }^{16)}$, 運動ニューロ 
ン疾患筋 ${ }^{16)}$, 実験的除神経筋 ${ }^{17)}$ は正常以上の反応 を示すと報告されている，colchicineによる神経 軸索流ブロックでは, 当該筋の対カフェイン異常 反応はみられず，神経伝導性括よび神経終末から のアセチルコリン遊離がブロックされた状態のと きのみに異常反応が発現するといら ${ }^{18)}$.われわれ の実験的除神経筋でも, 神経筋伝達ブロックが発 現した時期での対カフェイン反応は, 張力発生加 速度 $\left(\mathrm{d}^{2} \mathrm{Pt} / \mathrm{dt}^{2}\right)$ と弛緩時間 $\left(\mathrm{T}^{1} /{ }_{2} \mathrm{R}\right)$ の異常増大に 伴つて, 単収縮力 $(\mathrm{Pt})$ の正常範囲を越えた増大 がみられた（Fig 6 中央・印），一方，廃用筋の それは正常または正常以下の反応に止まり（Fig 6 中央×印)，ヒト・ジストロフィー筋のin vitro

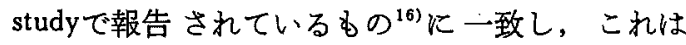
筋自体の因子の異常の反映であろらことを示唆す る。

中枢神経系には影響のない筋弛緩剤として, 臨 床的にも広く用いられているダントロレンは, 神 経筋伝達, 筋細胞膜電気的性質には影響すること なく，笳小胞体 $\mathrm{Ca}^{++}$遊離阻害によつて単収縮張 力低下 (強縮張力や高濃度 $\mathrm{K}^{+}$にるる筋contracture には影響が少ない)をもたらすことが知られて おり, trigger $\mathrm{Ca}^{++}$influx $\rightarrow \mathrm{Ca}^{++}$-induced $\mathrm{Ca}^{++}$ release from sarcoplasmic reticulumを阻害する 機序が示唆されている ${ }^{19)}$ ．われわれの正常家鬼前 怪骨筋について，ダントロレンに対する筋張力の 反応をみた結果も，主に張力発生加速度 $\left(\mathrm{d}^{2} \mathrm{Pt} / \mathrm{dt}^{2}\right.$ $=$ Active state intensity of shortening, 笳小胞体 $\mathrm{Ca}^{++}$遊離に関与) の変化に伴う単收縮力 $(\mathrm{Pt})$ の 低下であつた，収縮・弛緩時間，強縮張力とそ の発生速度 $\left(\mathrm{TdPt} / \mathrm{dt}, \mathrm{T}^{1} / 2 \mathrm{R}, \mathrm{Po}, \mathrm{dPo} / \mathrm{dt}\right)$ などが 受ける影響は軽度に止まつた（Fig 5 右; Fig 6 右shadow). 従つてカフェインとは少なくとも一 部作用部位が同じで，かつ，拮抗することが推定 されるが，カフェインで考劣られている筋小胞体 $\mathrm{Ca}^{++}$uptake過程に対する作用は，ダントロレン では否定されている，すなわち，筋小胞体 $\mathrm{Ca}^{++}$ 遊離促進に基づくとされる高濃度カフェインによ る caffeine-contractureは，つよく本剤の影響をう
け，主に筋小胞体 $\mathrm{Ca}^{++}$uptake阻害によるとされ る低濃度カフェインによる単収縮張力増大現象に 対しては本㓮の拮抗力は弱い，また，カフェイン により増大された単収縮力よりる， $\mathrm{NO}_{3}{ }^{\top}$ によつ て増大された単収縮力の方が，本剂の拮抗作用を つよくうけるといら ${ }^{20)}$. $\mathrm{NO}_{3}$-との拮抗を考えれ ば，ダントロレンの作用部位としてT systemの関 与も考虑される．以上のように，ダントロレンは 必ずしもカフェインと作用部位を同じくしないと 思われるので，疾患筋の本刘に対する反応を調べ る実験を行なつた。 その結果，ヒト・ジストロフィ 一筋は正常ヒト母指内転筋の反応程度範囲内にあ り (Fig 7), 家鬼の除神経, 廃用前怪骨筋 む正 常コントロールのそれの範囲内にあつた（Fig 6 右・， ×印)．ダントロレンの薬理作用が標的と するE-C couplingの一過程は，ジストロフィー， 除神経，筋活性低下のいずれの病的プロセスで る，少なくともそれらの或る時期には，機能的に 侵かされ難いことが示唆される。

ヒト・ジストロフィー筋でみとめられた筋細胞 内機構の諸要素異常を, denervation, immobilizationの㬰験筋検討の結果と関連付け，Fig 9 K要 約した。一部をのぞいて，ジトトフィ一筋の病 態をもたらす機序が，神経因子と筋自体の活性両 者の組み合せである場合が多く，必ずしも単一で

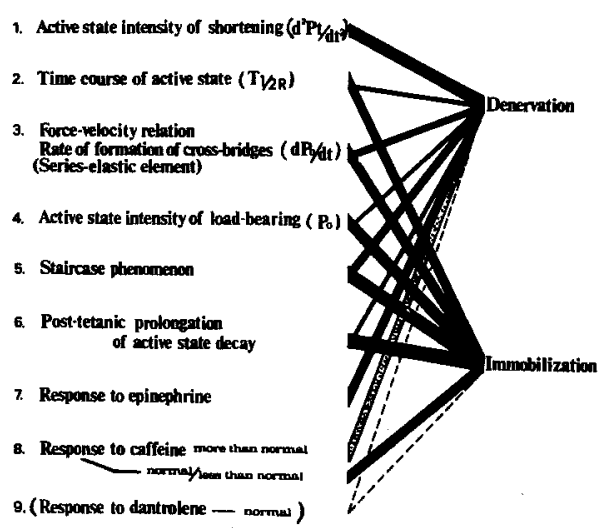

Fig 9. Contractile abnormalities in dystrophic muscles with normal electrical activities. 
ないことが暗示される、本実験の結果のみから は，神経因子が問題となる場合，その筋に対す るtrophic influenceはアセチルコリンそのるのに よるか, アセチルコリン以外のtrophic substance （s）がありらるかは結論出来ない．また筋自体 の活性が問題となる場合も，廃用筋でみられる細 胞内機構異常が, nerve activityのパターンの変 化（phasic，tonic神経放電パーンの変化）にか かるtrophic effectによるか，笳にかかる機械的ス トレスの変化によるかの鑑別は容易ではない。

\section{文献}

1) Takamori $M$ : Contractility and supersensitivity to adrenaline in dystrophic muscle. J Neurol Neurosurg Psychiat 88: 438, 1975.

2) Takamori $M$, et al: Contractile properties of human skeletal muscle. Arch Neurol 25: 535, 1971.

3) Takamori M: Nerve, muscle, and serotonin. J Neurol Neurosurg Psychiat 40: 89, 1977.

4) Taylor SR, et al: Mechanical threshold as a factor in excitation-contraction coupling. J Gen Physiol 54: $352,1969$.

5) Sreter FA: Effect of denervation on fragmented sarcoplasmic reticulum of white and red muscles. Exp Neurol 26: 52, 1972.

6) Close RI: Dynamic properties of mammalian skeletal muscles. Physiol Rev 52: 129, 1972.

7) Kean CJC, et al: Dynamic properties of denervated fast and slow twitch muscles of the cat. J Physiol 237: 103, 1974.

8) Drachman DB and Johnston DM: Neurotrophic regulation of dynamic properties of skeletal muscle: Effects of botulinum toxin and denervation. J Physiol 252: 657,1975
9) Buller AJ and Lewis DM: Further observations on the differentiation of skeletal muscles in the kitten hind limb. J Physiol 176: 355, 1965.

10) Desmedt JE and Hainaut K: Kinetics of myofilament activation in potentiated contraction: Staircase phenomenon in human skeletal muscle. Nature 217 ; $529,1968$.

11) Close R and Hoh JFY: The after-effects of repetitive stimulation on the isometric twitch contraction of rat fast skeletal muscle. J Physiol 197: 461, 1968.

12) Hoh JFY: Neural regulation of muscle activation. Exp Neurol 45: 241, 1974.

13) Close $R$ and Hoh JFY: Posttetanic potentiation of twitch contractions of cross-innervated rat fast and slow muscles. Nature 221: 179, 1969.

14) Bowman WC, et al: A comparison between the effects of a tetanus and the effects of sympathomimetic amines on fast- and slow-contracting mammalian muscles. Brit J Pharmacol Chem 19: $464,1962$.

15) Weber $A$ and Herz R: The relationship between caffeine contracture of intact muscle and the effect of caffeine on reticulum. J Gen Physiol 52: 750, 1968.

16) Gruener R, et al: Caffeine-modulated acetylcholine sensitivity in denervated rat and diseased human muscle. Life Sci 17: 1557, 1975.

17) McArdle JJ and albuquerque EX: A study of the reinnervation of fast and slow mammalian muscles. J Gen Physiol 61: 1, 1973.

18) Albuquerque EX, et al: The effects of vinblastine and colchicine on neural regulation of muscle. Ann NY Acad Sci 228: 224, 1974

19) Ebashi S: Excitation-contraction coupling. Ann Rev Physiol 38: 293, 1976

20) Homma I, et al: Effect of dantrolene sodium on excitation-contraction coupling of frog toe muscle. Jap J Physiol 26: 53, 1976. 